Journal for Social Action in Counseling and Psychology

Volume 4, Number 2, Fall 2012

\title{
A Critical Psychology of the Postcolonial: The Mind of Apartheid
} By Derek Hook

London: Routledge, 2012. ISBN: 9780415587570.

Reviewed by Shadi Gholizadeh, San Diego State University / University of California at San Diego, Joint Doctoral Program in Clinical Psychology. Email: shadigholizadeh@gmail.com

A Critical Psychology of the Postcolonial takes us on an elegant journey in understanding the constitutive relationship between postcolonial theory, Lacanian psychoanalysis, and critical psychology. After reading the text, it is difficult not to wonder how it would be possible to fully analyze not only the post-colonial mind of apartheid but racism in general without such grounding. Just as Fanon was able to define his unique brand of postcolonial theory through the combination of psychology and politics, so Hook has carved out an under-examined perspective on what Stephen Frosh terms in the foreword to the text as "the triangularly tense relationship between critical and discursive psychology, postcolonial theory and Lacanian Psychology" ( $p$. ix). A Critical Psychology of the Postcolonial brings together the motley voices of major postcolonial theorists, seminal political figures, and psychologists from a wide spectrum of psychological disciplines into what he himself terms as "critical liberation psychology". Hook's contribution lies in his ability to take the voices of seemingly unlikely bedfellows, such as Freud, Biko, Said, Žižek and Fanon, to provide the narrative for a distinctive story of racism, apartheid and post-apartheid South Africa.

The text weaves together psychology and postcolonial analysis to overcome the "disciplinary partitioning" (p. 6) that has too often relegated critical and cultural theory outside the realm of psychology - an unfortunate elision Hook posits as possibly stemming from an entrenched aversion to critical theory by the behemoth voice of positivist psychology. A Critical Psychology of the Postcolonial takes the reader on an analytical peregrination through existing social psychological, critical discursive, and postcolonial theorizations to demonstrate the value of linking postcolonial critique with politically engaged psychological approaches vis-à-vis the first four chapters' focus on a key topic in social psychology. These chapters provide a solid discussion around resistance psychology and Black Consciousness; extra-discursive abjecting features of racism and embodiment; underlying tenets of postcolonial psychoanalysis; and an extension of Homi Bhabha's analysis of racial stereotype and libidinal economy.

Following the foundation laid by the first four chapters, the final chapter provides the reader with a more intimate understanding of Hook's own unique brand of 'liberation psychology', to more fully understand the political and cultural layers of the "crisis of embodiment" via a psychoanalytic framing. As Hook concedes early on - a point affirmed by Frosh in his foreword the text is characterized with impasses, perhaps most obviously that of the white-apartheidraised and educated intellectual attempting to represent an entire corpus of Black Consciousness literature and thought. There are numerous other entanglements and 
impenetrable concrete walls by way of the "antagonism of the real". For example, Fanon describes whites as "sealed in their whiteness" and blacks "sealed in their blackness", commenting also on the inescapable projection of embodiment on blackness. Hook argues that it is within such socio-political irreconcilabilities that the fuel and sustenance for racism is housed. It is through the motifs of the "antagonism of the real" and "irresolvability" that the undercurrents of (post)colonial racism -- apparent in forms of denigration and abjection, in the 'theft of enjoyment' and colonialism's foundational Manichaeism - can best be understood.

A Critical Psychology of the Postcolonial makes a compelling case for moving beyond social construction to get at the messy irrationality of racism that lies beyond discursive consciousness. With its inclusion of recurring excerpts spanning such sources as the Apartheid Archive Project and the painful, autobiographical recounting of Frantz Fanon, $A$ Critical Psychology of the Postcolonial adds flesh to the "bloodless image of racism" (p. 54) with which purely discursive analyses of racism leave us. Indeed, as Hook reminds us of the colonial context, "This....was a racism of the sensory field, where fixations on visible markers of bodily differences were omnipresent; where the belief that others not only looked, but sounded, smelled essentially different was common place..." (p. 61). This focus on the embodiment of racism allows the reader to more fully understand the irretractability of the impasse of communicability. In so doing, Hook further offers us a critical understanding of abjection that goes beyond the purely descriptive and in so doing introduces new possibilities for analyses of racism undertaken by social psychologists. The text pushes previous conceptualizations to capture what Clarke (2003) calls "the sheer rapidity, the explosive, almost eruptive quality of ethnic hatred..." that provides the undercurrent for racism (p. 54). It is through, for example, the juxtaposition of Fanon's powerful descriptions of the violent racist discourse that was thrust upon him with Lacanian concepts such as jouissance that the reader can fully process the extradiscursive elements of racism.

A Critical Psychology of the Postcolonial promotes an innovative thinking around race and the post-colonial that has the potential to be hugely important in guiding social and community psychologists and activists. For the human service professional with goals of social transformation and community organizing, understanding the mechanisms that contribute to racism through this lens can be incredibly useful in developing a realistic perspective of the pervasiveness of racism in their communities. One the one hand, the model of a post-apartheid South Africa can be motivating in showing the removal of an institutionalized and systematic racism. On the other, that same model also highlights that even a systematic socio-political upheaval was not enough to overcome the more insidious, entrenched racism that still persists. Utilizing the approach to understanding racism espoused by $A$ Critical Psychology of the Postcolonial, however, researchers and activists alike can more thoughtfully unpack and react to the underpinnings of postcolonial racism.

Hook is successful in providing an innovative understanding of the embodiment of race and specifically, the violent and hyper-sexualized lens through which the black body is viewed in apartheid racism. I will have to add a caveat to Frosh's description of the "clarity" of Hook's text in describing it as a useful tool for students and academics exploring the topics of apartheid, race, critical and social psychology, and psychoanalysis. A Critical Psychology of the Postcolonial is an important contribution to the oft-neglected role of psychology in post-colonial studies; its innovative qualities - the ability to create a new dialogue between psychology (social, critical, and psychoanalytic, no less) and post-colonial studies - also creates a challenge for the author. 
While most readers will quickly appreciate Hook's solid analysis, the aforementioned clarity will only be appreciated by those with at least a foundational understanding of both postcolonial studies and psychoanalysis. For those unfamiliar in either or both of these disciplines, a fair amount of patience and parallel self-study is necessary to familiarize oneself with some of the key terms, for example the Lacanian concepts of the "Real" and jouissance, and key figures, for example Frantz Fanon and Homi Bhabha, as they are recurring presences throughout the text. That being said, the activist well-versed in these areas who adopts the conceptual vocabulary espoused by $A$ Critical Psychology of the Postcolonial has the potential to create truly transformational social change, while working within the socio-political confines that Hook articulates, as this is an innovative approach to race that gets to heart and blood of what sustains the racialized subject in our postcolonial landscape. By keeping the pervasive embodiment of racism in mind, activists can transcend discourse-analytic-informed approaches to social change that fail to capture "body-ego-symbolic" and simultaneous "symbolic-ego-body" "series of expulsions" (p. 46) that A Critical Psychology of the Postcolonial teaches us we cannot avoid.

A Critical Psychology of the Postcolonial boasts that rare quality to which many scholarly texts strive, namely, being relevant to a wide spectrum of audiences and falling under a vast umbrella of disciplines and activities. The solid theoretical and conceptual frameworks brought to life here render the text a highly valuable addition to the libraries of students and academics of postcolonial studies and critical psychology and an incredibly useful addition to the toolkits of human service professionals working in multicultural settings and activists committed to system transformation.

\section{References}

Clarke, S. (2003). Social theory, psychoanalysis and racism. New York: Palgrave. 